\title{
Shifting cancer care towards Multidisciplinarity: the cancer center certification program of the German cancer society
}

Christoph Kowalski ${ }^{1 *}$ (D) Ullrich Graeven ${ }^{2}$, Christof von Kalle ${ }^{3}$, Hauke Lang ${ }^{4}$, Matthias W. Beckmann ${ }^{5}$, Jens-Uwe Blohmer ${ }^{6}$, Martin Burchardt ${ }^{7}$, Michael Ehrenfeld ${ }^{8}$, Jan Fichtner ${ }^{9}$, Stephan Grabbe ${ }^{4}$, Hans Hoffmann ${ }^{10}$, Heinrich Iro ${ }^{5}$, Stefan Post ${ }^{11}$, Anton Scharl ${ }^{12}$, Uwe Schlegel ${ }^{13}$, Thomas Seufferlein ${ }^{14}$, Walter Stummer ${ }^{15}$, Dieter Ukena ${ }^{16}$, Julia Ferencz ${ }^{17}$ and Simone Wesselmann ${ }^{1}$

\begin{abstract}
Background: Over the last decades numerous initiatives have been set up that aim at translating the best available medical knowledge and treatment into clinical practice. The inherent complexity of the programs and discrepancies in the terminology used make it difficult to appreciate each of them distinctly and compare their specific strengths and weaknesses. To allow comparison and stimulate dialogue between different programs, we in this paper provide an overview of the German Cancer Society certification program for multidisciplinary cancer centers that was established in 2003.
\end{abstract}

Main body: In the early 2000s the German Cancer Society assessed the available information on quality of cancer care in Germany and concluded that there was a definite need for a comprehensive, transparent and evidencebased system of quality assessment and control. This prompted the development and implementation of a voluntary cancer center certification program that was promoted by scientific societies, health-care providers, and patient advocacy groups and based on guidelines of the highest quality level (S3). The certification system structures the entire process of care from prevention to screening and multidisciplinary treatment of cancer and places multidisciplinary teams at the heart of this program. Within each network of providers, the quality of care is documented using tumor-specific quality indicators. The system started with breast cancer centers in 2003 and colorectal cancer centers in 2006. In 2017, certification systems are established for the majority of cancers. Here we describe the rationale behind the certification program, its history, the development of the certification requirements, the process of data collection, and the certification process as an example for the successful implementation of a voluntary but powerful system to ensure and improve quality of cancer care.

Conclusion: Since 2003, over 1 million patients had their primary tumors treated in a certified center. There are now over 1200 sites for different tumor entities in four countries that have been certified in accordance with the program and transparently report their results from multidisciplinary treatment for a substantial proportion of cancers. This led to a fundamental change in the structure of cancer care in Germany and neighboring countries within one decade.

Keywords: Multidisciplinarity, Certification, Quality of care, Quality indicators

\footnotetext{
*Correspondence: kowalski@krebsgesellschaft.de

1 German Cancer Society, Department for Certification, Kuno-Fischer-Strasse 8,

14057 Berlin, Germany

Full list of author information is available at the end of the article
} 


\section{Background}

In addition to breakthroughs that have been made in the diagnosis and treatment of cancers, considerable effort over the last 20 years has been put into ensuring that the state of the art of care is translated into everyday care for the entire population in need. Indeed, this issue is at the heart of the debate about the quality of cancer care and how to improve it [1-5]. Numerous campaigns have been initiated that aim at translating the best available medical knowledge and treatment into clinical practice. They typically define standards for how to measure, compare, and improve the quality of care and how to best incorporate multidisciplinarity [6-12].

Some initiatives have also developed certification and accreditation programs for quality assurance and quality development using rigorous data collection processes, quality indicators, on-site auditing and peer review. These campaigns are partly government-driven, but most have been initiated by professional associations [12-16]. The inherent complexity of the programs and discrepancies in the terminology used make it difficult to appreciate each of them distinctly and compare their specific strengths and weaknesses. To allow comparison and stimulate dialogue between different programs, we describe here the certification system organized by the German Cancer Society (Deutsche Krebsgesellschaft, DKG). We explain the rationale for the certification program, the development of the certification requirements, the process of data collection, and the certification process.

\section{Discussion}

\section{Rationale and brief history of the program}

In the early 2000s, analyses of the limited data available suggested that despite enormous financial resources the results regarding cancer survival in Germany were only moderate compared to the results obtained in other European countries [17]. This resulted in several initiatives aimed at improving care, such as the development of clinical guidelines of the highest quality level for the most frequent cancer entities and a novel Cancer Center
Certification Program by the DKG. This program was initially introduced for breast cancer following the example of the EUSOMA effort (European Society of Breast Cancer Specialists, $[14,18]$ ) and soon afterwards also for other types of cancer. The program was intended to put evidence-based guideline recommendations into practice in everyday care and to place multidisciplinary teams at the heart of the cancer care process. To ensure that evidence-based standards are met in the certified units an auditing system based on quality metrics was implemented. The Cancer Center Certification Program was originally initiated, and has since been continually developed, by the professional associations involved in cancer care, working groups, and patient advocacy groups. Participation in the certification system is voluntary. This means that there is no official (government) body that requests certification in order to be able to provide a particular cancer service, and the government is not involved in defining the criteria for certification.

The centers established within the DKG certification system are tumor-specific networks (for an overview of the various types of center, see Fig. 1) in which patients are treated in a comprehensive, interdisciplinary, and multi-professional manner. Disciplines that are essential for the treatment of a particular cancer are specifically defined for each type of center. In breast cancer centers for example these teams comprise gynecologists, radiologists, pathologists, medical oncologists, radiotherapists, and specialists in nuclear medicine (termed "main cooperation partners"). In addition, written agreements for on request services have to be made with representatives of the following fields: oncological nursing, psychooncology, hospice/palliative medicine, social services, patient advocacy groups, genetic counseling, physiotherapy, laboratory medicine, and supplier of medical products [19].

\section{Development of the DKG cancer centers in Germany}

Shortly after the publication of the first Eurocare results [17], the DKG and the German Society for Breast

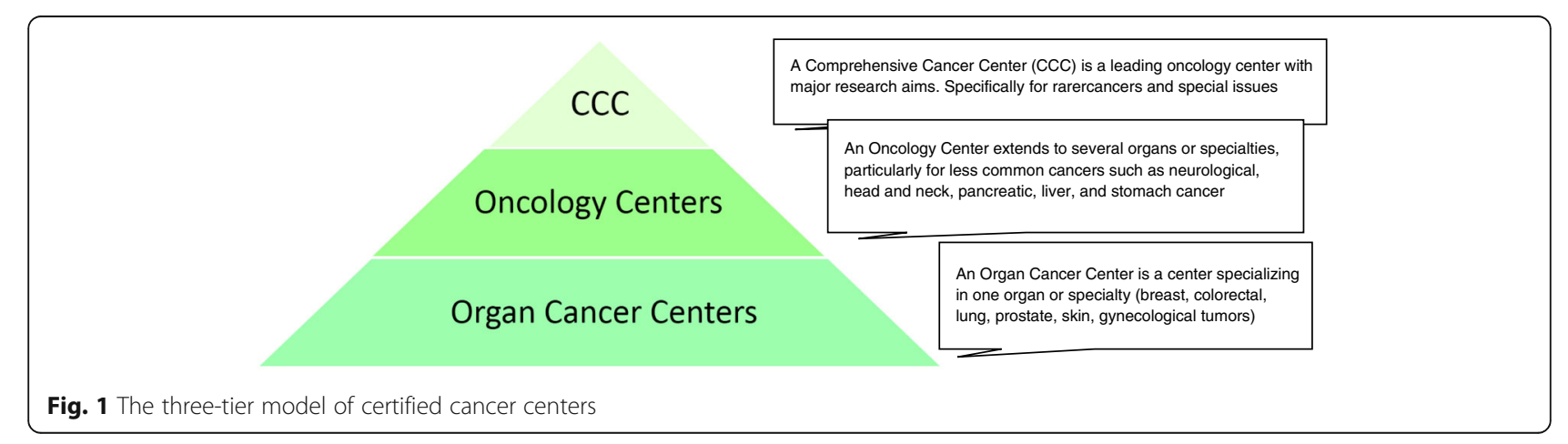




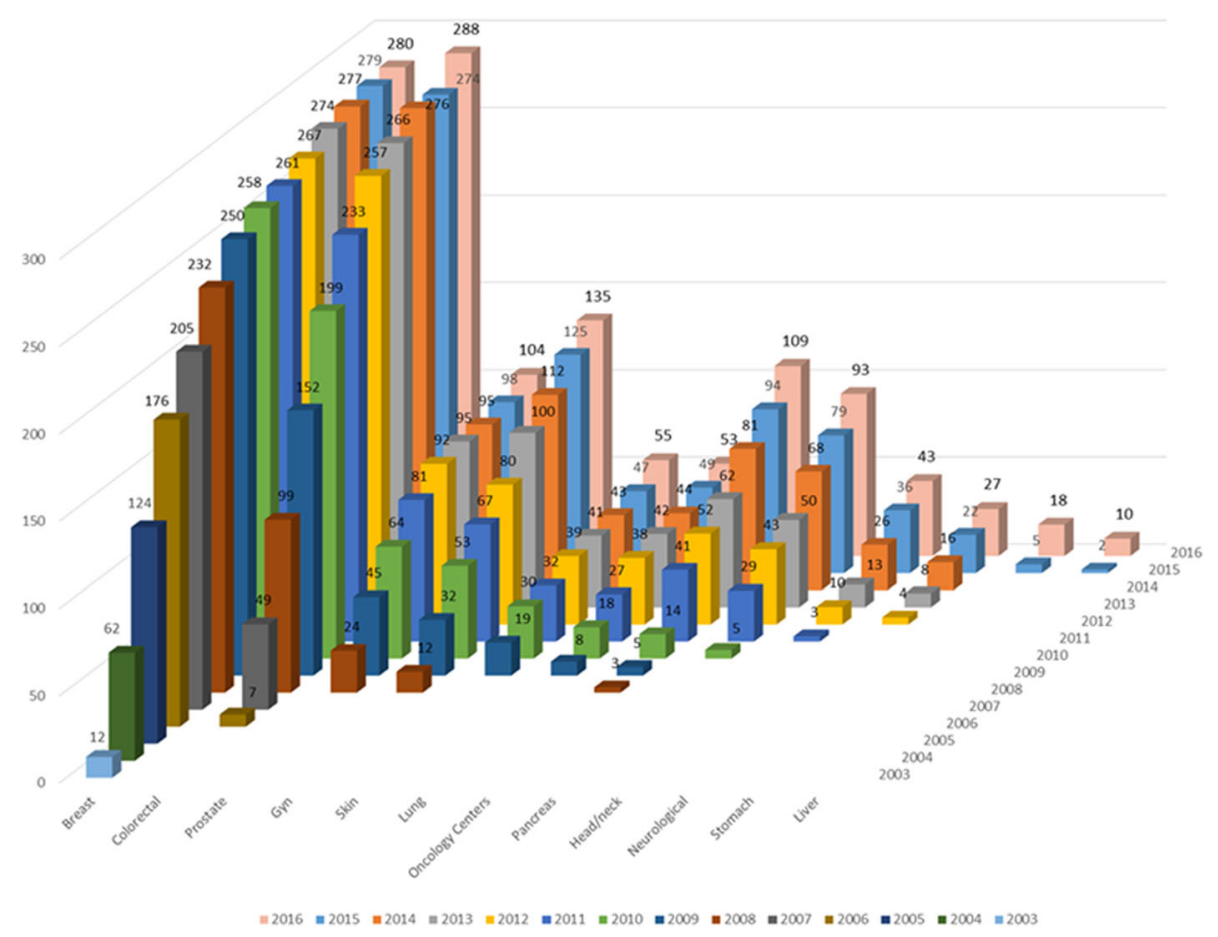

Fig. 2 Numbers of center sites, 2003-2016

Diseases (Deutsche Gesellschaft für Senologie, DGS) established the first set of criteria for certified cancer centers in accordance with the national clinical guidelines for breast cancer [20]. Subsequently, colorectal cancer centers (2006), skin cancer centers, gynecological cancer centers, lung cancer centers, and prostate cancer centers (all in 2008) were added to the certification program, each following guidelines of the highest quality level for the respective cancer entity. Each program has overlapping, general standards but also contains a set of distinct, cancer-specific requirements. Some of these requirements are translated into quality metrics that allow for comparisons across the different sites all over the country. The centers cover the whole spectrum of care for the respective tumor including prevention, early detection, treatment of the primary and advanced tumors, supportive and palliative care as well as psychooncology, social support and self-help groups.

Table 1 Current status of the certification system

\begin{tabular}{|c|c|c|c|c|c|c|c|c|c|c|c|}
\hline & \multicolumn{6}{|c|}{ Organ cancer centers } & \multicolumn{3}{|l|}{ Modules } & \multirow{2}{*}{$\begin{array}{l}\text { Oncology } \\
\text { centers }\end{array}$} & \multirow{2}{*}{$\begin{array}{l}\text { Comprehensive } \\
\text { cancer centers }\end{array}$} \\
\hline & Breast & Colorectal & Gynecological & Skin & Lung & Prostate & $\begin{array}{l}\text { Head/neck } \\
\text { tumors }\end{array}$ & $\begin{array}{l}\text { CNS } \\
\text { tumors }\end{array}$ & Pancreas & & \\
\hline $\begin{array}{l}\text { Current first } \\
\text { certification }\end{array}$ & 4 & 7 & 6 & 5 & 5 & 7 & 6 & 8 & 5 & 6 & \\
\hline Certified center & 230 & 280 & 133 & 55 & 45 & 103 & 41 & 26 & 91 & 97 & \\
\hline Certified center sites & 280 & 288 & 135 & 55 & 53 & 104 & 43 & 27 & 93 & 109 & 15 \\
\hline Primary cases, 2015 & 54,230 & 26,660 & 12,306 & $11,209^{b}$ & 17,731 & 19,932 & $6273^{c}$ & $5456^{d}$ & 4070 & 35,670 & \\
\hline $\begin{array}{l}\text { New cases of } \\
\text { cancer }^{\mathrm{a}}\end{array}$ & 70,170 & 62,230 & 26,140 & 20,820 & 52,520 & 63,710 & $15,628^{\mathrm{c}}$ & - & 16,730 & - & \\
\hline Total share & $74.6 \%$ & $41.4 \%$ & $43.6 \%$ & $50.8 \%$ & $32.9 \%$ & $29.6 \%$ & $37.5 \%$ & - & $22.9 \%$ & - & \\
\hline Center sites abroad & 11 & 10 & 9 & 4 & 2 & 7 & 4 & 1 & 6 & 6 & \\
\hline
\end{tabular}

CNS, central nervous system

a Based on German registry data from 2012

${ }^{b}$ Only includes malignant melanoma

'New cases of head and neck tumor: mouth and pharynx ICD-10 C00-C06, C09-C14, larynx C32

${ }^{\mathrm{d}}$ Neuroendocrine tumors (C70-C75, in the International Classification of Diseases for Oncology, ICD-O)

eNumerator: primary patients from centers in Germany, denominator: primary cases in Germany

As of: 31 December 2016, does not include data on the two most recently added modules (liver, stomach) 
The DKG program operates as part of the German National Cancer Plan led by the German Ministry of Health [21], that laid down a three-tier model of cancer centers in Germany consisting of Organ Cancer Centers (C), Oncology Centers (CC), and Comprehensive Cancer Centers (CCC, funded by the German Cancer Aid) (Fig. 1) [22]. Patient care must meet the same quality requirements in all aspects irrespectively of the institution and of its position in the three-tier model of the National Cancer Certification Program [23].

As of January 2017, there are 1200 certified Organ Cancer Centers, 109 Oncology Centers, and 15 Comprehensive Cancer Centers in Germany. Fig 2 demonstrates that this still entirely voluntary program is continuously growing. By now, approximately $40 \%$ of the population in Germany with primary cancers for which centers have been established are treated in certified institutions (Table 1). The geographic distribution of centers is illustrated in Fig. 3. Sixty sites are currently located in countries neighboring Germany - Italy, Switzerland, and Austria.

\section{Certification: Structure, standards, and fulfillment}

To provide the greatest possible degree of professional independence for those who develop and review the requirements and their implementation, and to avoid individual conflicts of interest, the certification system is

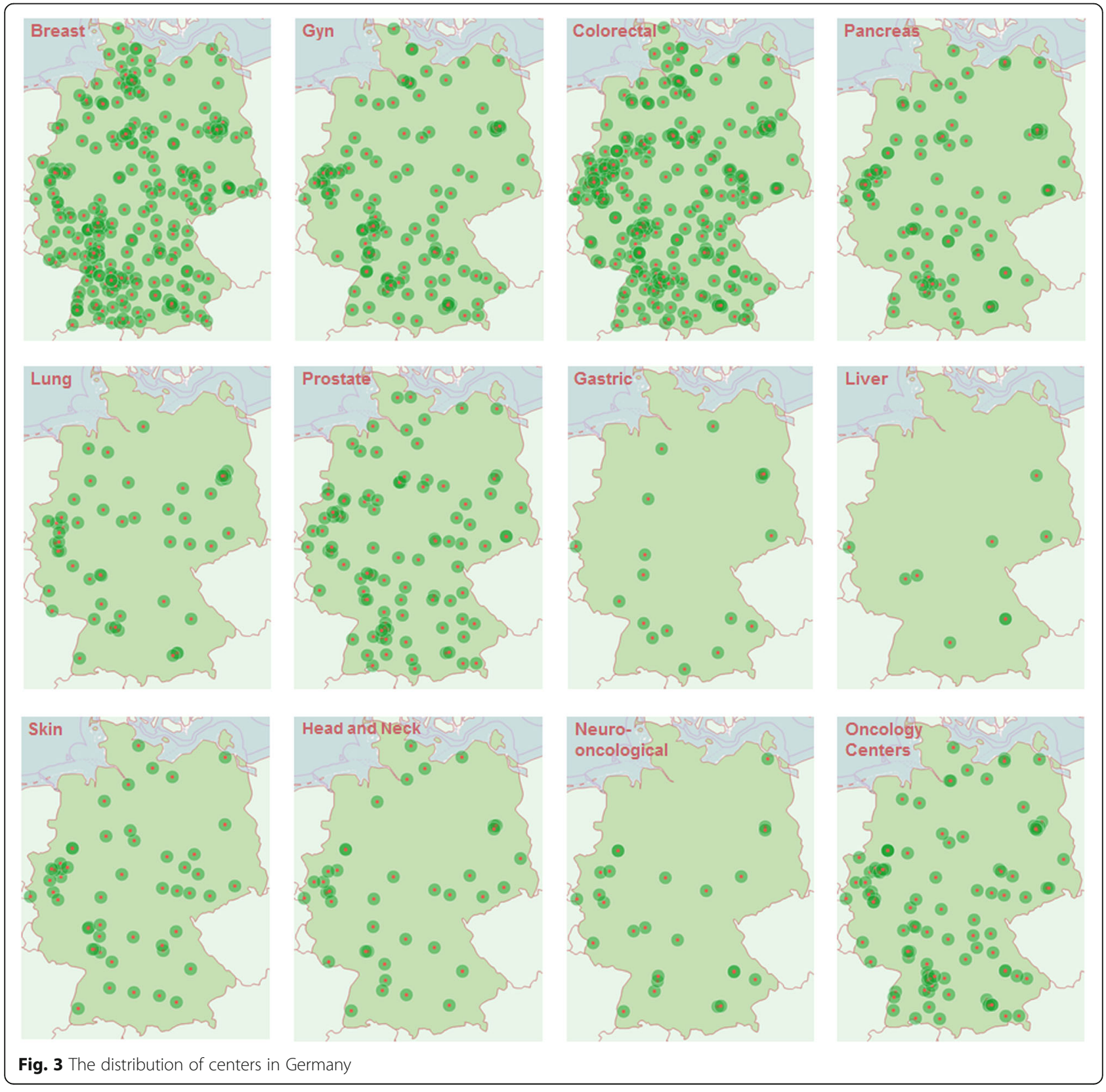


divided into three branches that work independently of each other (Fig. 4 "Separation of Powers").

1. The cancer type-specific Certification Committee (corresponding to a "legislative" body): This committee defines and develops the requirements specification for the certification of the respective centers based on evidence-based clinical guidelines of the highest quality (S3 level, with S standing for "Stufenklassifikation" or "step classification") and supplemented by recent research results that are not yet part of the guidelines or refer to structural requirements e.g., staffing or technical infrastructure. The clinical guideline categories as defined by the German Association of the Scientific Medical Societies (AWMF) range from S1 to S3, with S1 being based on expert consensus only and $\mathrm{S} 3$ (the highest level) being evidence based, i.e. based on a systematic literature review following defined criteria; having a representative guideline panel including patients; and using a formal consensus finding process. Based on the core recommendations of the guidelines, quality indicators are derived and implemented into the certification requirements [24]. Recent research results and structural requirements, unless suggested by clinical guidelines, are based on expert consensus in the respective Certification Committee, allowing for example patients to suggest requirements that are then discussed. Each cancer-specific Certification Committee consists of 30-40 experts of all specialties and professional groups involved that have been delegated by their respective professional medical society, by scientific societies, working groups, and self-help organizations. The Certification Committees convene annually or biennially to discuss the results from the certified centers and ensure timely updates of the requirements specification.

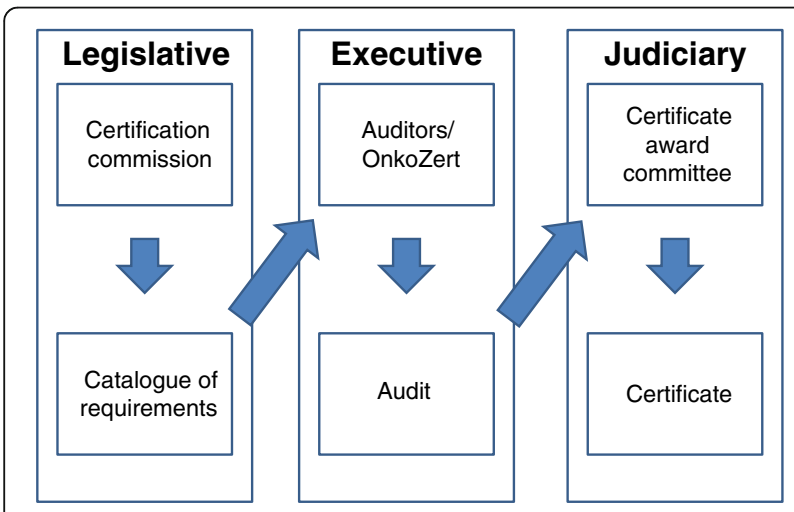

Fig. 4 The separation of powers in the certification system
2. Audit and data evaluation (corresponding to an "executive" body): To obtain the certificate for a specific cancer center the applicants must comply with the standards set out in the requirements specification developed by the relevant Certification Committee of the DKG. Data on the requirements are documented by each center using an electronic reporting system. Data are then reported to an independent certification institute, OnkoZert, where the documentation is formally checked for completeness and plausibility. To assure independence, OnkoZert manages the documents, organizes the audits and commissions the auditors but cannot influence the decision of awarding the certificate. Specially trained oncological medical experts from various specialties including surgery, pathology, gastroenterology, medical oncology, gynecology (i.e., the auditors) verify the implementation of the requirements and the validity of the documentation. Verification of the implementation of the requirements is done during an on-site audit of the documentation, of structures and processes at the centers. During these audits, the auditors examine actual patient files and discuss the results with the centers at the end of the site visit. The auditors prepare a written report about the data and the on-site visit. If any non-compliance with the certification requirements is observed during the audit, the auditor pronounces a so-called "deviation". The center then has three months to remedy this deviation starting from the audit day. Positive remedying is the precondition for the award of the certificate. The auditors include a recommendation about the award of a certificate in their report. If the center fails to remedy a deviation, the auditor will recommend to not issue the certificate. Auditors must not be members of the Certification Committee.

3. Certificate Award Committee (corresponding to "jurisdiction"): The final decision whether to award or deny a certificate is taken by another independent body, the Certificate Award Committee. This committee consists of three medical experts who are not involved in the corresponding audit. The Committee awards or denies the certificates based on the audit report and the auditors' recommendations. In 2016, 117 new certificates have been awarded and 14 certificates have been withdrawn because of not sufficient audit results.

\section{Data reporting}

All data from the tumor documentation of the respective centers are submitted electronically to the independent certification institute OnkoZert. Here, a software called 
Table 2 Example quality indicators for each center/module type

\begin{tabular}{|c|c|c|c|c|c|}
\hline $\begin{array}{l}\text { Center/ } \\
\text { module }\end{array}$ & Quality indicator definition & Target value & $\begin{array}{l}\text { Sites meeting the } \\
\text { target in } 2015\end{array}$ & Median & Source \\
\hline Breast & $\begin{array}{l}\text { Pretreatment histological confirmation } \\
\text { (numerator: patients with pretreatment } \\
\text { histological diagnosis confirmation by } \\
\text { means of a punch or vacuum biopsy; } \\
\text { population: patients with initial procedure } \\
\text { and histology showing invasive breast } \\
\text { cancer or DCIS as primary disease) }\end{array}$ & $\geq 90 \%$ & $97.5 \%(268 / 275)$ & $97.6 \%$ & $\begin{array}{l}\text { Annual Report of Certified Breast } \\
\text { Cancer Centers 2016 —Quality } \\
\text { Indicators (in English) } \\
\text { doi:10.13140/RG.2.1.1805.7204 }\end{array}$ \\
\hline Colorectal & $\begin{array}{l}\text { Quality of the TME rectum specimen } \\
\text { (information from pathology; numerator: } \\
\text { patients with good to moderate quality } \\
\text { TME [grade 1: mesorectal fascia or grade 2: } \\
\text { intramesorectal excisions]; population: } \\
\text { patients with radically operated rectal } \\
\text { cancer) }\end{array}$ & $\geq 70 \%$ & $98.5 \%(257 / 261)$ & $95.2 \%$ & $\begin{array}{l}\text { Annual Report of Certified Colorectal } \\
\text { Cancer Centers 2016 - Quality } \\
\text { Indicators (in English) } \\
\text { doi:10.13140/RG.2.1.3771.8001 }\end{array}$ \\
\hline Prostate & $\begin{array}{l}\text { Percutaneous radiotherapy with hormone } \\
\text { ablation therapy for locally confined } \\
\text { prostate carcinoma with high risk } \\
\text { (numerator: primary cases with additional } \\
\text { neoadjuvant and/or adjuvant hormone } \\
\text { ablation therapy; population: primary cases } \\
\text { with prostate carcinoma T1-2 NO MO with } \\
\text { high risk (PSA }>20 \mathrm{ng} / \mathrm{mL} \text { or Gleason } \\
\text { score } \geq 8 \text { or clinical stage T2c) and } \\
\text { percutaneous radiotherapy }\end{array}$ & $\begin{array}{l}\text { No target in } \\
2015\end{array}$ & - & $\begin{array}{l}71.43 \% \\
\text { (93 sites) }\end{array}$ & $\begin{array}{l}\text { Annual Report of Certified Prostate } \\
\text { Cancer Centers 2016 - Quality } \\
\text { Indicators (in English) } \\
\text { doi:10.13140/RG.2.1.3673.4969 }\end{array}$ \\
\hline Lung & $\begin{array}{l}\text { Combined chemoradiotherapy in stage } \\
\text { IIIA4/IIIB (numerator: combined } \\
\text { chemoradiotherapy in NSCLC primary cases } \\
\text { in stage IIIA4/IIIB with ECOG 0/1; population: } \\
\text { NSCLC primary cases in stage IIIA4/IIIB }\end{array}$ & $\begin{array}{l}\text { No target in } \\
2015\end{array}$ & - & $39.6 \%$ & $\begin{array}{l}\text { Annual Report of Certified Lung } \\
\text { Cancer Centers 2016 — Quality } \\
\text { Indicators (in German) } \\
\text { doi:10.13140/RG.2.1.3998.6327 }\end{array}$ \\
\hline Skin & $\begin{array}{l}\text { Malignant melanoma: sentinel-node biopsy } \\
\text { (SNB, numerator: primary cases in which } \\
\text { SNB was carried out; population: primary } \\
\text { cases of primary cutaneous melanoma with } \\
\text { a tumor thickness of } \geq 1 \mathrm{~mm} \text { and no evi- } \\
\text { dence of locoregional or distant metastasis) }\end{array}$ & $\geq 80 \%$ & $72.7 \%(32 / 44)$ & $85.2 \%$ & $\begin{array}{l}\text { Annual Report of Certified Skin } \\
\text { Cancer Centers 2016 - Quality } \\
\text { Indicators (in German) } \\
\text { doi:10.13140/RG.2.1.2227.2408 }\end{array}$ \\
\hline Ovary & $\begin{array}{l}\text { Postoperative chemotherapy for advanced } \\
\text { ovarian carcinoma (numerator: primary } \\
\text { surgical cases of FIGO IIB-IV ovarian } \\
\text { carcinoma with postoperative } \\
\text { chemotherapy; population: primary surgical } \\
\text { cases of FIGO IIB-IV ovarian carcinoma and } \\
\text { chemotherapy) }\end{array}$ & $\begin{array}{l}\text { No target in } \\
2015\end{array}$ & - & $96.4 \%$ & $\begin{array}{l}\text { Annual Report of Certified } \\
\text { Gynecological Cancer Centers } 2016 \\
\text { - Quality Indicators (in German) } \\
\text { doi:10.13140/RG.2.1.1052.0568 }\end{array}$ \\
\hline Cervix & Histological confirmation & $\begin{array}{l}\text { No target in } \\
2015\end{array}$ & - & $100.0 \%$ & $\begin{array}{l}\text { Annual Report of Certified } \\
\text { Gynecological Cancer Centers } 2016 \\
\text { - Quality Indicators (in German) } \\
\text { doi:10.13140/RG.2.1.1052.0568 }\end{array}$ \\
\hline $\begin{array}{l}\text { Head- } \\
\text { neck }\end{array}$ & $\begin{array}{l}\text { Imaging in patients with oral cavity } \\
\text { carcinoma to determine } \mathrm{N} \text { category } \\
\text { (numerator: patients with } \mathrm{CT} \text { or MRI } \\
\text { examinations of the region from the cranial } \\
\text { base to the superior thoracic aperture to } \\
\text { determine the } \mathrm{N} \text { category; population: } \\
\text { primary cases of patients with oral cavity } \\
\text { carcinoma) }\end{array}$ & $\begin{array}{l}\text { No target in } \\
2015\end{array}$ & - & $91.7 \%$ & $\begin{array}{l}\text { Annual Report of Certified Head and } \\
\text { Neck Tumor Centers } 2016 \text { - Quality } \\
\text { Indicators (in German) } \\
\text { doi:10.13140/RG.2.1.2788.7609 }\end{array}$ \\
\hline $\begin{array}{l}\text { CNS } \\
\text { tumors }\end{array}$ & $\begin{array}{l}\text { Interdisciplinary case discussions (numerator: } \\
\text { primary cases [elective patients: pre- } \\
\text { interventional, emergency patients: post- } \\
\text { interventional] presented at the tumor con- }\end{array}$ & $\geq 95 \%$ & $68.4 \%(13 / 19)$ & $96.4 \%$ & $\begin{array}{l}\text { Annual Report of Certified Neuro- } \\
\text { Oncological Tumor Centers 2016 - } \\
\text { Quality Indicators (in German) } \\
\text { doi:10.13140/RG.2.1.2788.7609 }\end{array}$ \\
\hline
\end{tabular}


Table 2 Example quality indicators for each center/module type (Continued)

\begin{tabular}{|c|c|c|c|c|c|}
\hline $\begin{array}{l}\text { Center/ } \\
\text { module }\end{array}$ & Quality indicator definition & Target value & $\begin{array}{l}\text { Sites meeting the } \\
\text { target in } 2015\end{array}$ & Median & Source \\
\hline Pancreas & $\begin{array}{l}\text { Lymph-node examination (numerator: } \\
\text { primary surgical cases of pancreas with } \geq 10 \\
\text { regional lymph nodes in the surgical } \\
\text { specimen after completion of surgical } \\
\text { treatment; population: primary surgical cases } \\
\text { in pancreas (OPS 5-524 ff., 5-525 ff. only } \\
\text { with ICD-10 C25) who have undergone } \\
\text { lymphadenectomy) }\end{array}$ & $\begin{array}{l}\text { No target value } \\
\text { in } 2015\end{array}$ & - & $90.0 \%$ & $\begin{array}{l}\text { Annual Report of Certified Neuro- } \\
\text { Oncological Tumor Centers } 2016 \text { - } \\
\text { Quality Indicators (in German) } \\
\text { doi:10.13140/RG.2.1.2788.7609 }\end{array}$ \\
\hline
\end{tabular}

CT, computed tomography; DCIS, ductal carcinoma in situ; DOI, digital object identifier; FIGO, Fédération Internationale de Gynécologie et d'Obstetrique; ICD, International Statistical Classification of Diseases and Health-Related Problems, 10th Revision; MRI, magnetic resonance imaging; NSCLC, non-small cell lung cancer; PSA, prostate-specific antigen; TME, total mesorectal excision

OncoBox that can interact with and extract data from the tumor documentation softwares used in Germany, runs a plausibility check of the data and calculates the quality indicators. Discrepancies are fed back to the centers for clearance. Cancer type and also center-specific results regarding the quality indicators are presented to the public in annual reports (e.g., [25]) and in scientific journals (e.g., [20, 26, 27]). Some of the requirements and quality indicators are the same for all center types and tumor entities, such as a study participation rate of $5 \%$ of patients, delivery of social services and psychooncological counseling to all patients, and discussion of all patients in specific multidisciplinary boards. However, most of the requirements are tailored to the specific center/tumor. As an example, one tumor-specific quality indicator for each center type is listed in Table 2. The quality indicators presented in the Table are derived from the clinical guidelines, unless otherwise indicated, and are part of the annual reports.

With the number of DKG certified centers outside Germany constantly increasing, the German Cancer Society's certification system has now become the largest in Europe. This provides many opportunities, including the ability to compare the quality of care not only within different regions of one country, but also across countries. Smaller countries with only a few centers, which would otherwise lack an appropriate comparator, can match their results with many centers from different countries and evaluate their development over time.

\section{Acquiring the certificate: The center perspective}

The certification criteria are outlined on the website of the independent certification institute OnkoZert (www.onkozert.de). Once a center has decided to apply for its initial certificate, it submits an inquiry form 3 to 6 months prior to the projected audit date. The inquiry form is reviewed by OnkoZert and a judgement is made on whether the center is in principle suitable for certification or whether its current structures make certification impossible. It is recommended that the centers then submit the necessary data 2 months prior to the audit date. The documents are formally reviewed and passed on to the responsible auditor(s), who provide(s) a written assessment about the contents. This assessment is then sent to the centers so that they can use it to make final adjustments regarding structures and processes. The subsequent on-site audit takes one or two days, depending on the type of audit, and includes auditing of all departments that shall participate in the certified center as well as of external cooperation partners. Relevant documents such as patient charts are reviewed on site and compared with the data submitted. Discrepancies between the actual situation and the certification criteria must be corrected within 3 months after the audit and are then re-evaluated by the auditor on paper or on site, depending on the specific issue. The auditor submits the audit report to OnkoZert, which verifies the data, and passes the audit report on to the Certificate Award Committee. Finally, the latter decides on denying or awarding of the certificate, which is then valid for 3 years. Full reevaluation-audits take place every 3 years, and surveillance audits - i.e., shorter audits focusing on the results for key figures and quality indicators are performed every year.

\section{Conclusions}

The DKG Cancer Center Certification program is a unique program: It is entirely voluntary, covers the most relevant tumor entities in a steadily increasing proportion, is based on guidelines of the highest quality, is run by experts in the field independent of governmental influence and comprises the whole spectrum of cancer care from prevention to screening, multidisciplinary treatment, social and psychooncological, supportive and palliative care. By implementing guidelines of the highest quality and the best available medical knowledge into everyday care it aims at comprehensively improving the quality of cancer care across all relevant tumor entities and across all regions. An important goal of the program is to also make quality of care transparent across all sites and thereby allowing to compare the centers based on 
objective indicators. This shall in turn stimulate mutual learning among the participating certified units.

The certification program has led to several paradigm shifts in Germany. Only three shall be outlined here. First and foremost, multidisciplinarity in cancer care has become widely established and is not limited to the multidisciplinary tumor boards. This is a development that would not have been foreseeable 15 years ago. The way in which the individual patient is treated no longer depends on one clinician alone, but includes expertise from the relevant providers within the network, who are specified by name. This multidisciplinary approach is not limited to medical specialties, but also includes psycho-social care [28] as well as nursing and palliative care, to which every patient is entitled. Secondly, the "separation of powers" in the certification system facilitates fair processes for the development and evaluation of requirements and for awarding certificates. Specific professional groups cannot play a dominant role. Thirdly, the collection and reporting of quality-of-care data that are implemented throughout the certification program [27], makes provider evaluation indicator-based and allows to compare the results and enables mutual learning. Indeed, due to the success of this program, comparisons are not limited to one country, but also include centers in other countries including Switzerland, Austria, and Italy. This provides an opportunity to make the quality of cancer care comparable on a European scale and to expand collaborations on this topic between scientific societies in different countries.

\section{Abbreviations \\ C: Organ Cancer Center; CC: Oncology Center; CCC: Comprehensive Cancer Center; DGS: Deutsche Gesellschaft für Senologie (German Society for Breast Diseases); DKG: Deutsche Krebsgesellschaft (German Cancer Society); EUSOMA: European Society of Breast Cancer Specialists; SNB: Sentinel-node biopsy}

\section{Acknowledgements}

Not applicable.

\section{Funding}

This research did not receive any specific grant from funding agencies in the public, commercial, or not-for-profit sectors.

\section{Availability of data and materials}

Not applicable, i.e. the raw data are not publicly available. However, the numbers presented in Tables 1 and 2 are taken from the respective annual reports as referred to in Table 2.

\section{Authors' contributions}

CK and SW drafted the first version of the manuscript, JF interpreted the data and developed the tables and figures. All authors contributed in writing to the manuscript during several rounds of discussion. All authors read and approved the final manuscript

\section{Ethics approval and consent to participate}

Not applicable, i.e., the study involves no human participants, human data or human tissue but only aggregated quality assurance information.

\section{Consent for publication}

Not applicable, i.e. the report does not involve individual person's data.

\section{Competing interests}

SW and CK are employees of the German Cancer Society and JF is an employee of the certification institute OnkoZert. All other authors are chairpersons or deputy chairs of one of the cancer type-specific certification committees or of the oncology centers certification committee as well as heads of certified centers.

Many of the authors received research funding or hold other financial relationships with (pharmaceutical) companies that are not in conflict with the work presented here. A full list will be provided by the corresponding author upon request.

\section{Publisher's Note}

Springer Nature remains neutral with regard to jurisdictional claims in published maps and institutional affiliations.

\section{Author details}

${ }^{1}$ German Cancer Society, Department for Certification, Kuno-Fischer-Strasse 8, 14057 Berlin, Germany. ${ }^{2}$ Kliniken Maria Hilf GmbH, Viersener Strasse 450, 41063 Mönchengladbach, Germany. ${ }^{3}$ NCT University Hospital, Im Neuenheimer Feld 460, 69120 Heidelberg, Germany. ${ }^{4}$ University Hospital, Langenbeckstrasse 1, 55131 Mainz, Germany. ${ }^{5}$ University Hospital, Universitätsstrasse 21-23, 91054 Erlangen, Germany. ${ }^{6}$ Charité University Hospital, Charitéplatz 1, 10117 Berlin, Germany. University Hospital, Fleischmannstrasse 42, 17489 Greifswald, Germany. ${ }^{8}$ University Hospital, Lindwurmstrasse 2a, 80337 Munich, Germany. ${ }^{9}$ Johanniter Krankenhaus, Steinbrinkstr. 96, 46145 Oberhausen, Germany. ${ }^{10}$ University Hospital, Im Neuenheimer Feld 460, 69120 Heidelberg, Germany. ${ }^{11}$ University Medical Center, Theodor-Kutzer-Ufer 1-3, 68167 Mannheim, Germany. ${ }^{12}$ Klinikum St. Marien, Mariahilfbergweg 7, 92224 Amberg, Germany.

${ }^{13}$ Knappschaftskrankenhaus, Dept. of Neurology, Ruhr-University Bochum, In der Schornau 23, 44892 Bochum, Germany. ${ }^{14}$ Ulm University Hospital, Albert-Einstein-Allee 23, 89081 Ulm, Germany. ${ }^{15}$ University Hospital, Albert-Schweitzer-Campus 1, 48149 Münster, Germany. ${ }^{16}$ Hospital Ost, Züricher Strasse 40, 28325 Bremen, Germany. ${ }^{17}$ OnkoZert GmbH, Certification Institute of the German Cancer Society, Gartenstrasse 24, 89231 Neu-Ulm, Germany.

Received: 25 September 2017 Accepted: 23 November 2017

Published online: 14 December 2017

\section{References}

1. Vardy J, Tannock IF. Quality of cancer care. Ann Oncol. 2004;15(7):1001-6.

2. Institute of Medicine. Delivering High-Quality Cancer Care: Charting a New Course for a System in Crisis. Edited by Levit L, Balogh E, Nass S, Ganz PA. Washington (DC): National Academies Press; 2013.

3. Aapro M, Astier A, Audisio R, Banks I, Bedossa P, Brain E, Cameron D, Casali $P$, Chiti A, De Mattos-Arruda L, et al. Identifying critical steps towards improved access to innovation in cancer care: a European CanCer organisation position paper. Eur J Cancer. 2017;82:193-202.

4. Borras JM, Albreht T, Audisio R, Briers E, Casali P, Esperou H, Grube B, Hamoir M, Henning G, Kelly J, et al. Policy statement on multidisciplinary cancer care. Eur J Cancer. 2014;50(3):475-80.

5. Cardoso F, Cataliotti L, Costa A, Knox S, Marotti L, Rutgers E, Beishon M. European breast cancer conference manifesto on breast centres/units. Eur J Cancer. 2017;72:244-50.

6. Valentini V, Glimelius B, Frascino V. Quality assurance and quality control for radiotherapy/medical oncology in Europe: guideline development and implementation. Eur J Surg Oncol. 2013;39(9):938-44.

7. Breugom AJ, Boelens PG, van den Broek CBM, Cervantes A, Van Cutsem E, Schmoll HJ, Valentini V, van de Velde CJH. Quality assurance in the treatment of colorectal cancer: the EURECCA initiative. Ann Oncol. 2014; 25(8)::1485-92.

8. Martin NE, Massey L, Stowell C, Bangma C, Briganti A, Bill-Axelson A, Blute M, Catto J, Chen RC, D'Amico AV, et al. Defining a standard set of patientcentered outcomes for men with localized prostate cancer. Eur Urol. 2015;67(3):460-7.

9. Valentini V, Abrahamsson P-A, Aranda SK, Astier A, Audisio RA, Boniol M, Bonomo L, Brunelli A, Bultz B, Chiti A, et al. Still a long way to go to achieve multidisciplinarity for the benefit of patients: commentary on the ESMO position paper (annals of oncology 25(1): 9-15, 2014). Ann Oncol. 2014;25(9):1863-5. 
10. Lamb BW, Sevdalis N, Taylor C, Vincent C, Green JS. Multidisciplinary team working across different tumour types: analysis of a national survey. Ann Oncol. 2012;23(5):1293-300.

11. Beets G, Sebag-Montefiore D, Andritsch E, Arnold D, Beishon M, Crul M, Dekker JW, Delgado-Bolton R, Fléjou J-F, Grisold W, et al. ECCO essential requirements for quality cancer care: colorectal cancer. A critical review. Crit Rev Oncol Hematol. 2017;1 10:81-93.

12. Valdagni R, Albers P, Bangma C, Drudge-Coates L, Magnani T, Moynihan C, Parker C, Redmond K, Sternberg CN, Denis L, et al. The requirements of a specialist prostate cancer unit: a discussion paper from the European School of Oncology. Eur J Cancer. 2011;47(1):1-7.

13. Saghatchian M, Thonon F, Boomsma F, Hummel H, Koot B, Harrison C, Rajan $A$, de Valeriola D, Otter R, Laranja Pontes J, et al. Pioneering quality assessment in European cancer centers: a data analysis of the organization for European cancer institutes accreditation and designation program. J Oncol Pract. 2014;10(5):e342-9.

14. EUSOMA: Position Paper. The requirements of a specialist breast unit. Eur J Cancer 2000, 36(18):2288-2293.

15. American College of Surgeons: National Accreditation Program for Breast Centers. NAPBC Standards Manual 2014 Edition. Chicago, IL; 2014.

16. Saghatchian M, Hummel H, Otter R, de Valeriola D, Van Harten W, Paradiso A, Koot B, Ringborg U, Tursz T. Towards quality, comprehensiveness and excellence. The accreditation project of the organisation of European cancer institutes (OECI). Tumori. 2008:94(2):164-71.

17. Sant M, Capocaccia R, Verdecchia A, Esteve J, Gatta G, Micheli A, Coleman MP, Berrino F. Survival of women with breast cancer in Europe: variation with age, year of diagnosis and country. The EUROCARE working group. Int J Cancer. 1998;77(5):679-83.

18. Brucker SY, Schumacher C, Sohn C, Rezai M, Bamberg M, Wallwiener D. Benchmarking the quality of breast cancer care in a nationwide voluntary system: the first five-year results (2003-2007) from Germany as a proof of concept. BMC Cancer. 2008;8(1):358.

19. Deutsche Krebsgesellschaft; Deutsche Gesellschaft für Senologie: Catalogue of requirements for Breast Cancer Centres, online at http://www.senologie. org/brustzentren/zertififzierungsrichtlinien. 2017. https://www. krebsgesellschaft.de/zertdokumente.html.

20. Kowalski C, Ferencz J, Brucker SY, Kreienberg R, Wesselmann S. Quality of care in breast cancer centers: results of benchmarking by the German cancer society and German Society for Breast Diseases. Breast. 2015;24(2): 118-23.

21. German Ministry of Health. National Cancer Plan. Berlin; 2012. http://www. bmg.bund.de/praevention/nationaler-krebsplan/was-haben-wir-bishererreicht/ziel-5-qualitaetssicherung-zertifizierung-onkologischerbehandlungseinrichtungen.html.

22. Beckmann MW, Adler G, Albers P, Bruns J, Ehninger G, Hauschild A, Neuhaus P, Schmiegel W, Schmitz S, Schmoll HJ, et al. Dreistufenmodell optimiert Behandlung unter Kostendeckung. Wie die künftigen Strukturen der onkologischen Versorgung in Deutschland aussehen sollten. Dtsch Arztebl. 2007:04:A3004-9.

23. Certification Committee Oncology Centres (German Cancer Society and German Cancer Aid): National Cancer Certification Programme. Catalogue of Requirements for Comprehensive Cancer Centres and Oncology Centres. Berlin; 2015.

24. German Guideline Program in Oncology (GGPO) of the German Cancer Society, German Cancer Aid and the Association of the scientific medical societies in Germany Working Group Methodology: Development of guideline based quality indicators. Methods paper for the German Guideline Program in Oncology. Version 1.0. Berlin; 2013.

25. Deutsche Krebsgesellschaft: Jahresbericht 2014 der zertifizierten Onkologischen Zentren. In. Berlin; 2014.

26. Singer S, Dieng S, Wesselmann S. Psycho-oncological care in certified cancer centres-a nationwide analysis in Germany. Psychooncology. 2013;22(6):1435-7.

27. Kowalski C, Schulte H, Wesselmann S, Reporting Program A. For cancer care quality indicators. J Oncol Pract. 2015;11(2)

28. Travado L, Breitbart W, Grassi L, Fujisawa D, Patenaude A, Baider L, Connor S, Fingeret M. 2015 President's plenary international psycho-oncology society: psychosocial care as a human rights issue-challenges and opportunities. Psychooncology. 2017;26(4):563-9.

\section{Submit your next manuscript to BioMed Central and we will help you at every step:}

- We accept pre-submission inquiries

- Our selector tool helps you to find the most relevant journal

- We provide round the clock customer support

- Convenient online submission

- Thorough peer review

- Inclusion in PubMed and all major indexing services

- Maximum visibility for your research

Submit your manuscript at www.biomedcentral.com/submit

) Biomed Central 